UDC 378.011.3-05(477) (73) DOI: http://doi.org/10.31617/k.knute.2019-10-10.108

Zvarych Iryna,

Doctor of Sciences (Pedagogics), senior staff scientist, Kyiv National University of Trade and Economics, 19, Kyoto str., Kyiv, 02156, Ukraine ORCID: 0000-0002-3772-4489

Researcher ID: P-3372-2018

\title{
APPROACHES TO THE FORMATION OF STUDENTS' LINGUISTICS PROFESSIONALISM AT THE HIGHER LEARNING INSTITUTIONS OF THE USA (foreign experience)
}

This article deals with the pedagogical approaches to the formation of the US students' linguistics professionalism, highlights the approaches to the formation of students' linguistics professionalism of Guy Strickland and Janell Cox; each approach to the formation of the students' linguistics professionalism at Higher Learning Institutions of the United States is analyzed and the subject teaching of American professor Raym M. Jones, who worked with students in Ukraine is highlighted. Following to the principle of historicism, we briefly analyzed the facts that were the impetus to the formation of the students' linguistis professionalism in the United States. In historical consideration, higher education in the United States has certain characteristics, namely, that the type of higher education in the United States has become a general higher education, which had a long path of formation.

The most important is the necessity to diversify teaching skills, combining knowledge and experience. In order to meet the requirements of the third millennium, the teacher has to master the new important skills which are necessary to the teacher in the process of the subject teaching, in particular, the following skills: tolerate, use the latest technologies, creativity, team play, management of on-line technologies, communication, searching the necessary resources on the Internet network, continuous education, the pace sense of studying the discipline, adaptation to new students and their abilities for studying the new subject materials.

Keywords: Higher Learning Institution, pedagogical approaches, formation the students' linguistics professionalism, modern development, motivation and skills.

Зварич Ірина. Підходи до формування професіоналізму з лінгвістики студентів у вищих закладах освіти США (зарубіжний досвід). 
У цุій статті розглянуто педагогічні підходи до формування професіоналізму американських студентів, висвітлено підходи до формування професіоналізму студентів Гая Стрікленда та Джейнлл Кокс; проаналізовано кожен підхід до формування професіоналізму студентів у вищих навчальних закладах США та висвітлено викладання навчальної дисиипліни американського професора Рейма Джонса, який праџював зі студентами в Україні. Дотримуючись методу історизму та компоративного аналізу, ми коротко проаналізували факти, що стали поштовхом до формування професіоналізму студентів США. В історичному плані вища освіта в США має певні характеристики, а саме те, що тип вищої освіти в США став загальною вищою освітою, яка мала довгий шлях становлення. Зокрема метод компоративного аналізу використовувався для дослідження підходів до формування професіоналізму студентів США і з'ясування спільних та відмінних підходів до формування професіоналізму студентів у вищих закладах освіти Украӥни і США.

Ключові слова: вищий навчальний заклад, педагогічні підходи, формування, професіоналізм студентів, розвиток освіти, мотивація, вміння, викладач.

Introduction. The new millennium is marked not only by the outlook of the world community in the future, the reform of higher education, the modernization of higher education institutions, but also by the qualitative level of students' preparation for useful further work, the formation of skills. It is important to build up-to-date education in the context of requirements and opportunities that meet international standards and have a qualitative approach to the learning process, including pedagogical approaches to the students' language training, in particular to the formation of the US students' linguistics professionalism. In order to successfully solve the problem of students' language training, especially to form the students' linguistics professionalism at higher leaning institutions in Ukraine, it is necessary to study foreign practice and introduce better experience in the educational process.

Aim and purpose of research. This exploration is devoted to the study of the pedagogical approaches to the formation of the US students' linguistics professionalism and language skills, so the purpose of this article is to explore the approaches to the formation of students' linguistics professionalism of Guy Strickland and Janell Cox; the coverage each approach to the students' language training at US higher learning institutions. Therefore, the purpose of the article is to highlight the pedagogical approaches to the formation of students' language training skills at US higher learning institution

Analysis of the basic research and publications. American scientists Guy Strickland (1998) and Janelle Cox prefer (2019) to highlight approaches to the skills developing of the US students. Guy Strickland (1998) highlights the learning process, 
including its positive and negative effects to gain the subject knowledge, and Genell Cox (2019) offers new approaches to the language training which are required to the formation of students' linguistics professionalism as in the US higher learning institutions and Ukrainian ones as well.

Karabulut-Ilgu, Cherrez and Jahren (2018) suggest the analysis of studies published in the period from 2000 to May 2015 on the use of inverted engineering education. The authors came to conclusion that inverted learning is very effective.

The research done by Chao, Chen and Chuang (2015) was also aimed at exploring the benefits of the inverted approach to learning for students. The researchers shared the results of the use of inverted learning to the study of projecting computers using high school bridges.

Summary of the main ideas. He development of pedagogical approaches to study the subject, in particular the students' language training and improving the quality of the education process at US higher learning institutions is due to a rethinking the teaching traditional forms and methods, an increase in the complex of new technologies, the widespread use of new, non-traditional forms of learning.

There is much progress has been done in the system of higher education in the United States. Due to the reforms in the American society, education is becoming more open and diverse. The process of meaningful study the learning subject is very important, in particular the formation of students' linguistics professionalism and the language training of students, because the programs in American institutions of higher education are aimed at obtaining a profession of narrow specialization.

The very important scientific work has been investigated by Guy Strickland's «Bad Teachers» (1998) where he points out that the success of a student's skills depends on the quality of the education process because it is a kind of mirror that impartially and accurately reflects a certain step of learning, provides an opportunity to reflect on whether time was spent effectively in the learning process and whether the state goals were being achieve. The American researcher rightly points out that if teachers unprofessionally carry out the education process and are light-hearted in determining the students 'knowledge level quality, in particular, do not check the written assignments, so they do not know how to do it, they do not have professional skills to correct mistakes, make adjustments in students' written works.

Despite the complexity of the US education system, Guy Strickland (1998) notes that the quality of education process, which is carried out in the classroom by the lecturer, depends on the success of US students' learning as a whole, because the level of studying material and skills are formed and the students' linguistics professionalism is formed as well. In his opinion, if students do not have time to complete the proposed tasks in the allotted time, it indicates that: they have not mastered the past educational 
material and are not ready to perceive the new ones; the offered studying tasks do not correspond to the level of requirements for the program of higher education institution, faculty, course; the teaching process had disadvantages and miscalculations in the lecturer's work during the subject learning; pedagogical process of determining the quality of students' knowledge level does not meet the modern standards, because a lot of allotted time is spent establishing discipline in the audience, explaining the proposed studying tasks, etc.

Nowadays, there is being payed the great attention to the latest technology in the US, the ability and skills of using the Internet resources, reproaches to the formation of students' linguistics professionalism, in particular highlighted ten important skills which are necessary to the teacher in the process of subject learning, including language training.

Janelle Cox (2019) notes that lecturers should diversify their teaching approaches, combining them with their knowledge and experience. In order to keep up with the requirements of the third millennium, the teacher must master the new important skills which are needed to the teacher in the process of subject teaching, in particular, the ability: to tolerate, use the latest technology, creativity, team play, managing online technologies, communication skills, resourcefulness on the Internet, continuous learning, a sense of the pace of study of the discipline, adaptation to new students and their ability to study the subject.

Ability to endure. The patience of the teacher, the ability to withstand the pranks of students, and sometimes to the indecent behavior and student response, then to understand and find common approaches to mastering the subject, in particular to the formation of students' linguistics professionalism. Due to the teacher's patience, his/her ability to wait, students do not embrace unnecessary emotions and he/she is in no hurry to do irritable actions. If the teacher has patience, then he/she is able to see, but not notice, hear, but not to listen. A such lecturer can hear a lot, but listen only that what he/she chooses. It is the wisdom to endure and see but not to look, to hear, but not to listen. If the teacher possesses this wisdom that comes through patience, then he/she is automatically able to use his/her intellect as a filter that leaves only what is necessary inside and cleans everything unnecessarily.

The ability to use the latest technologies is a necessity for modern teaching the learning subject - it is a requirement of the new millennium to keep up with the new technologies. The teacher must not only be able to use modern technologies, but also to know which digital device is suitable for students. State-of-the-art technologies help students to better develop their own cognitive abilities, enrich their own experience, help to know themselves, self-define and self-actualize, and form own professionalism that is needed for further employment. Thus, for shaping professional competences of 
future specialists it is necessary to apply innovative technologies: information computer technologies, project method, role games, etc. As experience shows, application of the above-mentioned technologies will enable improvement of methodological and other competences of teachers (O. Ustymenko, N. Maiier, 2018).

Creativity is the constant searching the original solutions for the solving the tasks, creativity of thinking and fantasy, the ability to see the sequence of actions and the final result. Janelle Cox (2019) notes that the most effective tool which a lecturer should use is his/her imagination. Because the Common Core State Standards (CCSS) are implemented in educational institutions, teachers think that they need to use their imagination more than ever, which is why lecturers should use creativity in the learning process and come up with unique ways to get interested students in the study the necessary materials for forming the students' linguistic professionalism.

Team play is the play when the teacher is involved to the work as part of team and he/she is the member of this team. Janelle Cox calls it the «team training» when the lecturer does the task together with students, and this gives to the students the better grasp of knowledge and gaining skills for their professional employment. As team play is a test, endurance, activity and preparation for future useful occupation, it is very important to introduce game moments in the course of studying the learning subject (I. Zvarych, S. Ralaur, N. Prymachenko, I. Romashchenko, I. Romanyshyna, 2019).

In the course of team play, students focus and strive to accomplish tasks for the other team, thus developing attention and creativity of thinking, and they do not notice that they are learning under the guidance of the teacher. As a rule, team games with elements of competition are fun and non-coercive. If such teamwork courses take place in the system of subject study, then this type of work brings tangible results in the development of students' linguistics professionalism, in particular to gain knowledge for further occupation.

Ability to manage on-line technologies. With the development of modern technologies, most teachers are online. Modern lecturers need to know how to manage their online technologies, as online activities are done in real time.

The development of on-line technologies, in particular information, promotes the development of students' intellectual abilities to study the learning subject, predict the results of their activities, develop a strategy for finding ways and methods for solving problems - both as educational and practical. The ability to manage online technology provides quick feedback between the teacher and students, and of course, the timely and successful completion the assignments of learning subject and forming the students' linguistic professionalism.

Communicativeness. Lecturers' ability to communicate with students, colleagues, teachers, parents is a teacher's skill to talk and maintain dialogue during the interview process. 
V. Kahn-Kalyk (1987) highlights the most effective communication skills, in particular, to communicate with students through a properly established communication system, to organize creative activities with students, the ability to purposefully organize and manage communication. The teacher can communicate only if he/she possesses certain communicative abilities, including emotions, a desire to share thoughts, feelings, sympathy emotions, such as likeness, dislike, respect to the students in the process of communication with them, etc. It is only the presence of these emotions and the need to realize them, which testify the teacher's inclination to communicate, his willingness to present the subject learning material.

Karabulut-Ilgu, Cherrez and Jahren (2018) suggest the communication in the process of learning subject, especially the inverted learning in education. $\mathrm{He}$ underlines that is the effective approach of education.

Finding the Internet resources underlines, the teacher's ability to use the online resources, including the ability to find creative tasks and engaging resources that will help to interest students in learning subject; search the new applications to use and browse the web-sites for carefully study the learning subject and improve your professional skills. The Internet offers great opportunities to use educational resources in the teacher's work, including access to resources as a tool for finding the necessary additional material for studying the learning subject, improving communication and intellectual experience, providing the existing world experience, etc.

For professional training of future specialists, it is very important to find the Internet resources which will enable the introduction of new methods into the educational process (O. Stavytskyi, M. Urazgaliyeva, 2018).

Scientists I. Ghritchenko, I. Nesterenko in their study prove the positive result of using Internet resources in the educational process to improve the efficiency and quality of training (Ghritchenko, I., \& Nesterenko, I., 2016).

Continuous learning is a prerequisite to improve the teachers' professionalism, as they aware that they should search the learning material and to be constantly searching for the truth and they are sure that too much knowledge could never be enough in their professional activity, so teachers try to attend seminars, master classes, and undergo advanced training, which will make them better in the course of teaching. It should be noted that there are many factors in the information society that make it necessary to constantly update the education received in order to provide up-to-date material for mastering the learning subject in a timely manner. That's why a teacher cannot carry out the learning process unless he/she possesses meaningful and in-depth knowledge of the subject being taught. Guy Strickland believes that a teacher cannot teach students mathematical actions, if he/she cannot add, the teacher cannot teach students to read or write, if he/she does not know the literature or makes mistakes in writing (G. Strickland, 1998). 
The approach of continuous learning is very important for students' interest in acquiring knowledge, skills, experience, motivating the participant in the learning process to continue education and forms the satisfaction from what has been achieved (D. Dicheva, C. Dichev, G. Agre, \& G. Angela, 2015).

Pace feeling the study of learning subject, the teachers should feel the pace of study the learning subject, in particular the students' willingness to determine the quality level of their knowledge. If the training program is exhausted, then the time for reviewing the learning material is taken, so the teachers slow down the rate of submission the new material in the process of teaching. In our humble mind, it's not necessary to be slow in studying, because it should better to review the learning material and aware it thoughtfully.

Adapting to the new students and their ability to study the learning subject, these skills must be shared by each teacher, as he/she needs to adapt to the new students in group before they start quickly master the learning subject and study the new material; to students' behavior of their requirements; lessons' plans and more. Knowing the material and be adapted to the new students, the lecturers are ready to communicate with students and discuss the learning topics professionally including students' interests and improving their professionalism, in particular the approaches to the formation of students' linguistics professionalism.

In the course of studying the learning material and mastering the subject, US lecturers tactfully remind their students that gaining meaningful knowledge in mastering the learning subject and gaining professional skills is necessary for the employment of future specialists, because higher American learning institutions do not guarantee their employment. To gain meaningful subject knowledge, students are offered compulsory curricula and additional courses for advanced subject study and to acquire the skills of professionalism. The best US institutions of higher learning give their students the opportunity to take courses that meet their individual needs and which are not in their university's plan, that's why they have the opportunity to increase their knowledge level, skills and acquirements needed for further occupation. That's why in the US, there is an agreement between universities to send their students from one institution of higher education to another one in order to study the additional courses of learning subjects, which are interesting to students for developing their skills and formation the linguistic professionalism, improving the quality of students' knowledge level. This exchange of students significantly influences the acquisition of informative knowledge in the process of study the learning subject, and the acquisition of appropriate skills and acquirements in forming professionalism, in particular the linguistic one for future employment.

The inter-university training organization in the USA is one of the most interesting, attracting European experts. Its main appeal is mobility. In addition to the 
basic theoretical learning subjects which are the cornerstone of studying, the curriculum includes comparing short specialized courses that can be quickly refined to reflect new developments in science and technology, and, if necessary, new crosscurricular courses can easily be developed to help training specialists in new areas which are dictated by scientific and technological progress.

Conclusion. The modernization of new forms and methods of teaching, in particular pedagogical approaches to the formation of students' linguistics professionalism, is an important means of improving the students' knowledge level and the quality of education as well. The analyzed approaches to the formation of US students' skills and acquirements can be used for formation the professionalism of students at higher learning institutions in Ukraine. First of all, the following pedagogical approaches to the formation of the students' professionalism, in particular the linguistic professionalism should be used in the process of studying the learning subjects: ability to endure, the ability to use the latest technologies, creativity, team play, ability to manage on-line technologies, communicativeness, finding the Internet resources, continuous learning, pace feeling the study of learning subject, adapting to the new students and their ability to study the learning subject. Preparing students from both Ukraine and the United States for future occupation involves certain personality traits: the ability to acquire knowledge independently; to improve skills and acquirements and bring them to automatism; the ability to think and process a large amount of information creatively and critically; communicativeness; ability to use the latest learning technologies.

\section{REFERENCES}

1. Cox Janell. (2019) 10 Useful Skills Modern Teachers Need / [Online resource] / Available at: https://www.thoughtco.com/useful-skills-modern-teachersneed-2081527 [in English].

2. Chih Yang Chao, Yuan Tai Chen, Kuei Yu Chuang. (2015). Exploring students' learning attitude and achievement in flipped learning supported computer aided design curriculum: A study in high school engineering education. Computer Applications in Engineering Education, 23, (4) 2015, 514-526. Doi: 10.1002/cae.21622 [in English].

3. Dicheva, D., Dichev, C., Agre G., Angelova, G. (2015). Gemification in education: a systematic mapping study. Education Technology \& Society V. 18 (3), 75-88.

4. Ghritchenko, I., \&Nesterenko, I. (2016). Innovative approaches to teaching English language to artists. Advanced Education, 6, 101-105. DOI: 10.20535/24108286.85954. [in English]. 
5. Kahn-Kalyk V. A. (1987). Teacher on pedagogical communication: Book. for teacher. 46-62.

6. Karabulut Ilgu, A., Cherrez, N. J., \&Jahren, C. T. (2018). A systematic review of research on the flipped learning method in engineering education. British Journal of Educational Technology, 49, (3), 398-411. [in English].

7. Stavytskyi, O., \&Urazgaliyeva, M. (2018). Using Google Classroom tools in teaching students of economic specialities. Advanced Education, 10, 69-75. DOI: 10.20535/2410-8286.149361. [in English].

8. Strickland G. Bad Teachers. (1998). The Essential Guide for Concerned parents. Pocket Books. 307 p. [in English].

9.Ustymenko, O., \& Maiier, N. (2018). Modern methods and technologies for developing pre-service foreign language and culture teachers' methodological competence. Advanced Education, 10, 5-11. DOI: 10.20535/2410-8286.133090. [in English].

10. Zvarych I.M., Ralaur S.M., Prymachenko N.M., Romashchenko I.V, Romanyshyna I.V. (2019). Gamification as a Tool for Stimulating the Educational Activity of Students of Higher Educational Institutions of Ukraine and the United States. Journal «European journal of Educational Research», V.8 (3), 875-891. [in English]. 